\title{
Candidate genes related to reproductive traits of Hereford and Braford bulls
}

\section{Genes candidatos relacionados a traços reprodutivos em touros Hereford e Braford}

\author{
Silvio Renato Oliveira Menegassi ${ }^{1}$; Gabriel Ribas Pereira²; Paulo Ricardo Loss \\ Aguiar $^{3}$; Katiana Santos Stelmach Pereira ${ }^{4}$; Celso Koetz Junior ${ }^{5}$; José Braccini \\ Neto $^{6}$; Vanessa Peripolli ${ }^{7}$; Carolina Gabriela Becker Berlitz ${ }^{8 *}$; \\ Júlio Otávio Jardim Barcellos ${ }^{6}$
}

\begin{abstract}
This study emphasized the importance of using candidate genes in predicting semen quality in bulls that can be used in cow-calf production. The aim of this study was to evaluate some candidate genes related to reproductive traits in Braford and Hereford bulls. All bulls $(\mathrm{n}=188)$ were submitted to breeding soundness evaluations at 24, 28, 32, and 36 months of age. The microsatellite markers ILSTS002 and BMS3004 associated with the luteinizing hormone- $\beta(L H \beta)$ gene, IDVGA-51 to leptin $(L E P)$ gene, HEL5 and AFZ1 within the IGF-IR gene, and two SNP markers (LHR and FSHR) associated with the $L H R$ and FSHR genes, respectively, were evaluated by the amplification of DNA products. The variation in the IDVGA-51 allele 177-185 showed polymorphic information content (PIC) associated with sperm motility and vigor traits in Hereford bulls. Hereford animals showed PIC of 0.36 to $0.75 \%$ along with expected heterozygosity $(\mathrm{H})$ of 0.49 to $0.78 \%$. Braford bulls that indicated the ILSTS002 allele $137-175$ and AFZ1 allele 113-119 showed PIC associated with major and minor defects, respectively. The PIC ranged from 0.28 to $0.78 \%$, with an expected $\mathrm{H}$ of 0.35 to $0.81 \%$. AFZ1 allele $121-127$ had the highest minor defects and ILSTS002 allele 125-135 showed the highest major defects from ejaculated semen in Braford bulls. In addition, IDVGA-51 allele 175 showed lower motility and vigor in Hereford bulls. The markers AFZ1 (IGF-IR) and ILSTS002 (LH $\beta)$ in Braford and IDVGA-51 (LEP) in Hereford bulls were effective in verifying the reproductive traits of the bulls.
\end{abstract}

Key words: Molecular markers. Single nucleotide polymorphisms. Microsatellites. Genetic variability. Braford and Hereford breeds.

\section{Resumo}

Este estudo enfatizou a importância do uso de genes candidatos na predição da qualidade do sêmen em touros que podem ser utilizados na produção de bezerros. O objetivo deste estudo foi avaliar alguns

\footnotetext{
Pesquisador, Universidade Federal do Rio Grande do Sul, UFRGS, Porto Alegre, RS, Brasil. E-mail: programa.paat@gmail.com

2 Pesquisador, Universidade do Norte do Paraná, UNOPAR, Londrina, PR, Brasil. E-mail: gabrielribaspereira@gmail.com

Prof., Universidade Luterana do Brasil, ULBRA, Canoas, RS, Brasil. E-mail: pauloraguiar@gmail.com

4 Técnica, ULBRA, Canoas, RS, Brasil. E-mail: stelmachpereira@gmail.com

5 Prof., UNOPAR, Londrina, PR, Brasil. E-mail: celsokoetzjr@gmail.com

Profs., UFRGS, Porto Alegre, RS, Brasil. E-mail: jose.braccini@ufrgs.br; julio.barcellos@ufrgs.brr

Prof ${ }^{a}$, Instituto Federal Catarinense, IFC, Araquari, SC, Brasil. E-mail: vanessa.peripolli@hotmail.com

8 Discente, UFRGS, Porto Alegre, RS, Brasil. E-mail: carolinaberlitzz@gmail.com

* Autor for correspondence
} 
genes candidatos relacionados a traços reprodutivos em touros de Braford e Hereford. Todos os touros $(\mathrm{n}=188)$ foram submetidos a avaliações reprodutivas aos $24,28,32$ e 36 meses de idade. Os marcadores microsatélites ILSTS002 e BMS3004 associados ao gene hormônio luteinizante- $\beta$ (LH $\beta$ ), o IDVGA-51 associado ao gene Leptina (LEP), o HEL5 e AFZ1 ao gene IGF-IR e dois marcadores SNP (LHR e FSHR) relacionados ao LHR e FSHR, respectivamente, foram avaliados pela amplificação de produtos de DNA. A variação no alelo IDVGA-51 177-185 mostrou conteúdo de informação polimórfica (PIC) associada à motilidade espermática e características de vigor nos touros de Hereford. Os animais Hereford apresentaram PIC de 0,36 a $0,75 \%$, juntamente com heterozigosidade esperada $(\mathrm{H})$ de 0,49 a 0,78\%. Os touros Braford que indicaram o alelo ILSTS002 137-175 e o alelo AFZ1 113-119 mostraram PIC associados a defeitos maiores e menores, respectivamente. O PIC variou de 0,28 a $0,78 \%$ com um $\mathrm{H}$ esperado de 0,35 a $0,81 \%$. O alelo AFZ1 121-127 teve os defeitos menores mais altos, enquanto, o alelo ILSTS002 125-135 mostroualtos defeitos maiores do sêmen ejaculado em Braford. Além disso, o alelo IDVGA-51 175 mostrou baixa motilidade e vigor nos touros Hereford. Os marcadores AFZ1 (IGF-IR) e ILSTS002 (LH $\beta$ ) em Braford e IDVGA-51 (LEP) no Hereford foram efetivos na verificação dos traços reprodutivos dos touros.

Palavras-chave: Marcadores moleculares. Polimorfismos de nucleotídeos únicos. Microssatélites. Variabilidade genética. Raças Braford e Hereford.

\section{Introduction}

Bull fertility is an economically important, complex feature known to be controlled by genetic as well as environmental factors. Bull breeding soundness evaluation (BBSE) includes measurement of the scrotal circumference (SC) as an important tool for evaluating fertility (KASTELIC; THUNDATHIL, 2008). The identification of candidate genes would enable the cattle industry to optimize the management of bulls to reduce the age at puberty, improve the ability to select early maturing bulls, and perhaps develop treatments to hasten the onset of puberty (FORTES et al., 2012).

Predicting reproductive potential is difficult and not always accurate from semen sample evaluation on the basis of conventional sperm viability or morphological assessment alone (RODRIGUEZMARTINEZ, 2007). HEL5 and AFZ1, located on BTA21 of the insulin growth factor I receptor $(I G F-I R)$ gene, are markers showing an association with greater calving interval (BARENDSE et al., 1997; OLIVEIRA et al., 2005). The leptin (LEP) gene is directly related to the presence of alleles for IDVGA-51 located on the BTA4 that indicate an increasing calving interval in cows (ALMEIDA et al., 2000). The genetic diversity in crossbred beef cows demonstrates that ILSTS002 and BMS3004 are associated with the luteinizing hormone- $\beta(L H \beta)$ gene on BTA18 that is associated with reproductive performance (SILVEIRA et al., 2013). In addition, receptors for luteinizing hormone $(L H R)$ and follicle stimulating hormone (FSHR) genes located at BTA11 are also involved in the regulation of several essential reproductive processes occurring at the gonadal level (CHENG, 1975; MA et al., 2012).

Fertility is a trait with low heritability, and therefore, the presence of a DNA marker can serve geneticists and breeders in evaluating animals as needed by the production system (BOLIGON et al., 2010). Studies indicate that candidate genes may be used as an alternative biomarker for selecting bulls with acceptable semen quality parameters but also emphasize the importance of new studies to validate their results with larger samples in different cattle breeds (DEB et al., 2013, 2015; WALDNER et al., 2010). Studies on the genetic control of fertility in bulls are scarce, and this topic needs intensive investigation to meet future needs (DEB et al., 2015; HENRICKS et al., 1998). Therefore, the aim of this study was to evaluate some candidate genes related to the reproductive traits of Braford and Hereford bulls. 


\section{Material and Methods}

This study was performed on two commercial farms in the state of Rio Grande do Sul, Brazil. The farms' geographical locations were $29^{\circ} 56^{\prime} 8.82^{\prime \prime}$ $\mathrm{S}$ latitude and $56^{\circ} 55^{\prime} 25.18^{\prime \prime} \mathrm{W}$ longitude in Uruguaiana (Braford; $\mathrm{n}=88$ ) and $31^{\circ} 19^{\prime} 53^{\prime \prime} \mathrm{S}$ latitude and $54^{\circ} 06^{\prime} 25^{\prime \prime} \mathrm{W}$ longitude in Bagé (Hereford; $n=100$ ). The climate is classified as Cfa according to the Köppen classification.

All bulls were kept in the same feeding conditions prior to the study, and the animals were tested for tuberculosis and brucellosis and were vaccinated against infectious bovine rhinotracheitis, bovine virus diarrhea, and leptospirosis. These bulls were followed throughout their development from 7 to 24 months. The animals were weaned at seven months of age and allocated to a ryegrass pasture (Lolium multiflorum) until 12 months; between 12 and 18 months of age, they were kept in a pasture with sorghum forage (Sorghum bicolor) and millet (Pennisetum americanum) grassland; and between 18 and 24 months of age, they were again kept on a ryegrass pasture. Throughout these periods, they received mineral supplementation and water ad libitum.

All animals showed a good body condition score throughout the experiment, with body condition scores ranging from 3.5 to 4.5 , where a score of one was thin and a score of five was fat. Blood samples and measurements of Scrotal Circumference (SC) were collected at seven months when the bulls were weaned and at 24 months of age.

The Bull Breeding Soundness Evaluation(BBSE) classifies animals according to SC by age as well as quantitative and qualitative aspects of the ejaculated semen. Animals were classified into three categories in terms of reproductive potential: $60-100$ points (satisfactory), 30-59 points (questionable), and 0-29 points (unsatisfactory) according to Chenoweth (2000). The SC was measured by pulling the testes down to the bottom of the scrotum and positioning a centimeter tape around the largest circumference. The SC was adjusted for age and weight using correction factors. Basically, we used the average SC for Braford bulls collected over two years (34.9 \pm two standard deviations; $5.8 \mathrm{~cm}$ ) and the average SC for Hereford bulls collected over two years (36.4 \pm two standard deviations; $6.4 \mathrm{~cm}$ ) to identify bulls with the lowest SC. Then, we excluded animals with an SC equal to or less than $29 \mathrm{~cm}$ and $30.5 \mathrm{~cm}$ in Braford and Hereford bulls, respectively, based on the corrected information of the mean and standard deviations as described by Menegassi et al. (2011).

Semen collection was first performed when the animals were 24 months old and then once every season for three consecutive seasons of the year. Thus, semen was collected at 24, 28, 32, and 36 months of age. The bulls were restrained and semen was collected from each bull using a manually operated electroejaculator, Autojac-Neovet (Autojac, Neovet, Campinas, SP, Brazil). For semen collection, the bulls were restrained to facilitate rectal probe insertion, feces were evacuated manually by insertion, and an electroejaculator probe with three ventrally oriented longitudinal electrodes was used to deliver a sequence of electrical impulses to each bull. The electrical stimulation ceased once a minimum sample of two milliliters was obtained, and the collection continued until the bull ceased to ejaculate.

Mass activity or wave motion was determined by placing a drop of semen on a pre-warmed microscope slide, and the edge of the drop was examined using 40x magnification. Mass motion received a score ranging from 0 to 5: $0=$ no swirl, $+=$ no swirl with generalized oscillation of individual sperm only, ++ = very slow distinct swirl, $+++=$ slow distinct swirl, $++++=$ moderately fast distinct swirl and eddies, and $+++++=$ fast distinct swirls and eddies with the appearance of good-quality semen. Sperm motility was examined under a bright-field microscope at a magnification of $100 \mathrm{x}$ with a $5 \mu \mathrm{L}^{-1}$ aliquot of semen placed on a warmed $\left(37^{\circ} \mathrm{C}\right)$ slide and covered with a coverslip. Sperm motility was evaluated as the percentage of sperm movement ( 0 to $100 \%$ ). Vigor was evaluated using a scale from 0 to 5 , based on 
sperm progressive movement, where $0=$ none, $1=$ very weak, 2 = weak, $3=$ intermediate, $4=$ strong, and $5=$ very strong.

In addition, each semen aliquot was diluted in buffered saline-formaldehyde (1:10), and sperm morphology was analyzed using a phase-contrast microscope. Sperm was also evaluated with eosinnigrosin staining using a bright-field microscope. Acrosome defects, abnormal heads, double heads, abnormally small heads, proximal protoplasmic droplets, midpiece defects, accessory tails, and strongly bent tails were considered major sperm defects. Minor sperm defects included distal protoplasmic droplets, abaxial implantations, bent tails, and detached heads. The total defects were determined based on 200 sperm cells from each animal, and a sperm classification was performed as previously described by the BBSE of the Western Canadian Association of Bovine Practitioners (BARTH; OMINSKI, 2000).

Blood samples were collected by puncture of the coccygeal vein, placed in a tube with anticoagulant, refrigerated, and transported to the laboratory. The samples were stored and DNA extraction was performed according to Miller et al. (1998). The five microsatellites or short tandem repeats (STRs) analyzed in this experiment were HEL5 $(151,153$, 155, 157, 163, 165, 167, and 169 alleles) and AFZ1 $(113,117,119,121,123,125$, and 127 alleles), which are associated with IGF-IR; ILSTS002 (125, $131,133,135,137,139,141$, and 175 alleles) and BMS3004 (125, 127, 129, 132, 135, and 138 alleles), which are associated with $L H \beta$; and IDVGA-51 (173, 175, 177, 179, 181, 183, and 185 alleles), which is associated with $L E P$. Each microsatellite was amplified by PCR using primers and specific annealing temperatures. The genetic markers and gene references used to evaluate reproductive parameters in beef cattle are presented in Table 1.

The reactions had a final volume of $25 \mu \mathrm{L}^{-1}$ and contained $50 \mathrm{ng} \mathrm{L}^{-1}$ of DNA. The amplified PCR products were analyzed by electrophoresis in a vertical $11 \%$ polyacrylamide gel in non-denaturing
Tris Boric Acid EDTA (TBE) buffer with $\mathrm{pH} 8.3$ at $300 \mathrm{~V}$ and $10 \mathrm{~mA}$ for approximately 24 hours. After being stained with silver nitrate, the fragments were analyzed in comparison with the control using a molecular weight marker of 25 bp. Two SNP markers (LHR and FSHR) were also evaluated; for these, DNA was amplified by PCR, and the product generated was fragmented with restriction enzymes, AluI and HalI, respectively. For the analysis of the SNP, the amplification product, which contains two fragments (400 and $690 \mathrm{bp}$ ), was digested with endonuclease Sau3A1 according to the manufacturer's protocol. The endonuclease cleaved the two fragments, enabling the identification of polymorphisms. For example, a 400-bp fragment in the absence of the restriction site corresponds to the A allele, whereas the B allele, while in Sau3A1, generated two products: one of $310 \mathrm{bp}$ and one of $90 \mathrm{bp}$. Similarly, the $690 \mathrm{bp}$ fragment is cleaved in carriers of allele 2, producing products of 470 and $220 \mathrm{bp}$, and allele 1 corresponds to the absence of the restriction site. DNA amplification was performed as described by Lahiri et al. (1997).

Genetic marker variability analysis was performed using expected heterozygosity $(\mathrm{H})$ and polymorphic information content (PIC) according to Nei (1978). An association study was realized using a statistical model, $\mathbf{y}=\mathbf{X} \boldsymbol{\beta}+\mathbf{Z u}+\mathbf{e}$ in which $\boldsymbol{\beta}$ is the vector that included the fixed effects of genetics, the contemporary group (same farm, year of birth, management group), age (linear and quadratic effects), weight (linear and quadratic effects), breed (linear effect), and individual $\mathrm{H}$ (linear effect); is the vector of the random effects of the animal; and is the vector of random residual effects. $\mathbf{X}$ and $\mathbf{Z}$ are incidence matrices that relate $\mathbf{y}$, the vector of observations, to fixed effects and random effects, respectively. Data were not adjusted, and physiological variables, SC, and seminal variables (motility, vigor, major defects, minor defects, and total defects) were analyzed by PROC GLM using $\mathrm{SAS}^{\circledR}$ v.9.3 (Statistical Analysis Software, Inst. Inc., Cary, NC). Significant differences were considered when $\mathrm{P}<0.05$. 


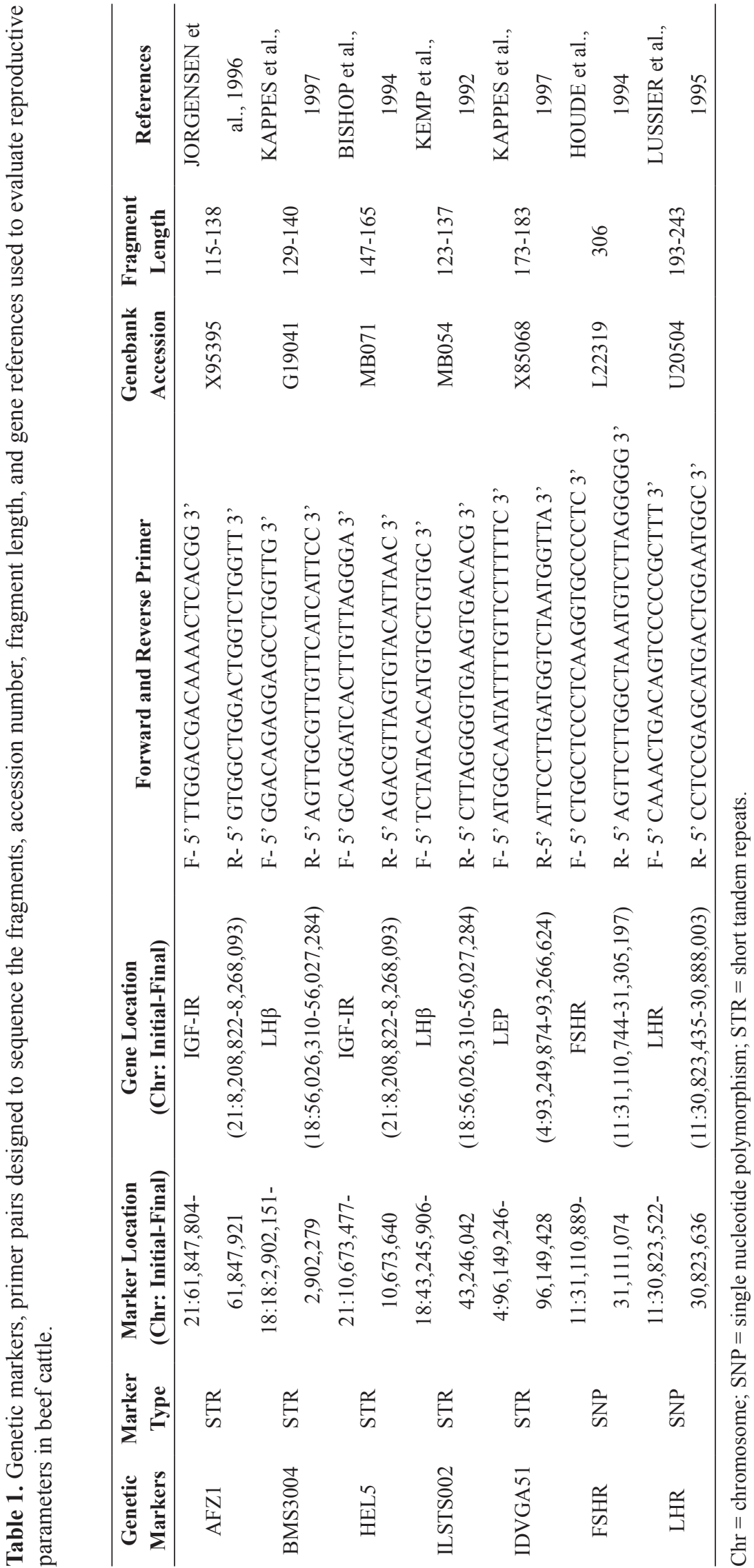




\section{Results}

In the present study, the overall mean \pm SEM observed for $\mathrm{SC}$ was $36.15 \pm 0.19 \mathrm{~cm}$. The mean sperm morphological characteristics observed in this study were $5.88 \pm 0.365,5.78 \pm 0.29$, and $11.67 \pm 0.56$ for the major, minor, and total defects, respectively. Overall, the bulls showed a mean of $77.75 \pm 0.11$ and $3.55 \pm 0.06$ for motility and vigor, respectively.

Allele frequencies for the STR and SNP markers for Braford bulls are presented in Table 2. The number of alleles in the STR markers varied from six in BMS3004 to eight in HEL5 and ILSTS002. The most frequent alleles were BMS3004*129, ILSTS002*135 and *139, IDVGA-51*175, HEL5*167, and AFZ1*121. The most frequent SNPs were LHRC and FSHR G alleles. The PIC ranged from 0.28 to 0.78 , with an expected $\mathrm{H}$ of 35 to $81 \%$. Associations were verified between the reproductive status of Braford bulls and allele classes for BMS3004, HEL5, IDVGA-51, LHR, and FSHR markers $(\mathrm{P}>0.05)$. However, Braford bulls with ILSTS002 and AFZ1 alleles showed $3.5 \%$ major and $3.4 \%$ minor defects, respectively $(\mathrm{P}<0.05$; Table 3$)$.

Table 2. Allele frequencies of seven molecular markers (five STRs and two SNPs) in Braford bulls.

\begin{tabular}{|c|c|c|c|c|c|c|c|c|c|c|}
\hline \multirow{2}{*}{$\begin{array}{l}\text { Markers } \\
\text { SRTs }\end{array}$} & \multicolumn{8}{|c|}{ Alleles (\%) } & \multirow[t]{2}{*}{$\mathbf{H}$} & \multirow[t]{2}{*}{ PIC } \\
\hline & & & & & & & & & & \\
\hline \multirow[t]{2}{*}{ AFZ1 } & 113 & 117 & 119 & 121 & 123 & 125 & 127 & & & \\
\hline & 4.5 & 18.6 & 21.2 & 24.4 & 18.6 & 11.5 & 1.3 & & 0.81 & 0.78 \\
\hline \multirow[t]{2}{*}{ HEL5 } & 151 & 153 & 155 & 157 & 163 & 165 & 167 & 169 & & \\
\hline & 6.4 & 21.8 & 9.6 & 0.6 & 2.6 & 21.2 & 28.2 & 9.6 & 0.81 & 0.77 \\
\hline \multirow[t]{2}{*}{ ILSTS002 } & 125 & 131 & 133 & 135 & 137 & 139 & 141 & 175 & & \\
\hline & 0.6 & 3.2 & 6.4 & 27.6 & 22.4 & 27.6 & 11.5 & 0.6 & 0.77 & 0.73 \\
\hline \multirow[t]{2}{*}{ IDGVA51 } & 173 & 175 & 177 & 179 & 181 & 183 & 185 & & & \\
\hline & 3.8 & 37.8 & 7.7 & 5.1 & 7.1 & 26.9 & 11.5 & & 0.75 & 0.72 \\
\hline \multirow[t]{2}{*}{ BMS3004 } & 125 & 127 & 129 & 132 & 135 & 138 & & & & \\
\hline & 3.8 & 2.6 & 48.7 & 35.3 & 3.2 & 6.4 & & & 0.64 & 0.57 \\
\hline \multicolumn{11}{|l|}{ SNPs } \\
\hline \multirow[t]{2}{*}{ LH-R } & $\mathrm{T}$ & $\mathrm{C}$ & & & & & & & & \\
\hline & 22.6 & 77.4 & & & & & & & 0.35 & 0.28 \\
\hline \multirow[t]{2}{*}{ FSH-R } & $\mathrm{G}$ & $\mathrm{C}$ & & & & & & & & \\
\hline & 60.7 & 39.3 & & & & & & & 0.47 & 0.36 \\
\hline
\end{tabular}

H, Nei's heterozygosity expected; PIC, polymorphism information content.

Allele frequencies for the STR and SNP markers for Hereford bulls are presented in Table 4. The number of alleles in the STR markers varied from five in BMS3004 to eight in HEL5 and ILSTS002. The most frequent alleles were BMS3004*125, ILSTS002*135, IDVGA-51*175, HEL5*165, and AFZ1*113. The most frequent SNPs were LHRC and FSHR G alleles. The PIC ranged from 0.36 to 0.75 , with an expected $\mathrm{H}$ of 49 to $78 \%$. Associations were verified between the reproductive status of Hereford bulls and allele classes for BMS3004, HEL5, AFZ1, ILSTS002, LHR, and FSHR markers $(\mathrm{P}>0.05)$. However, Hereford bulls with the IDVGA-51 allele showed $84.7 \%$ motility and 3.6 vigor, respectively $(\mathrm{P}<0.05$; Table 5$)$. FSHR and LHR allele associations in Hereford and Braford bulls for reproductive parameter status are showed in Table 6. 


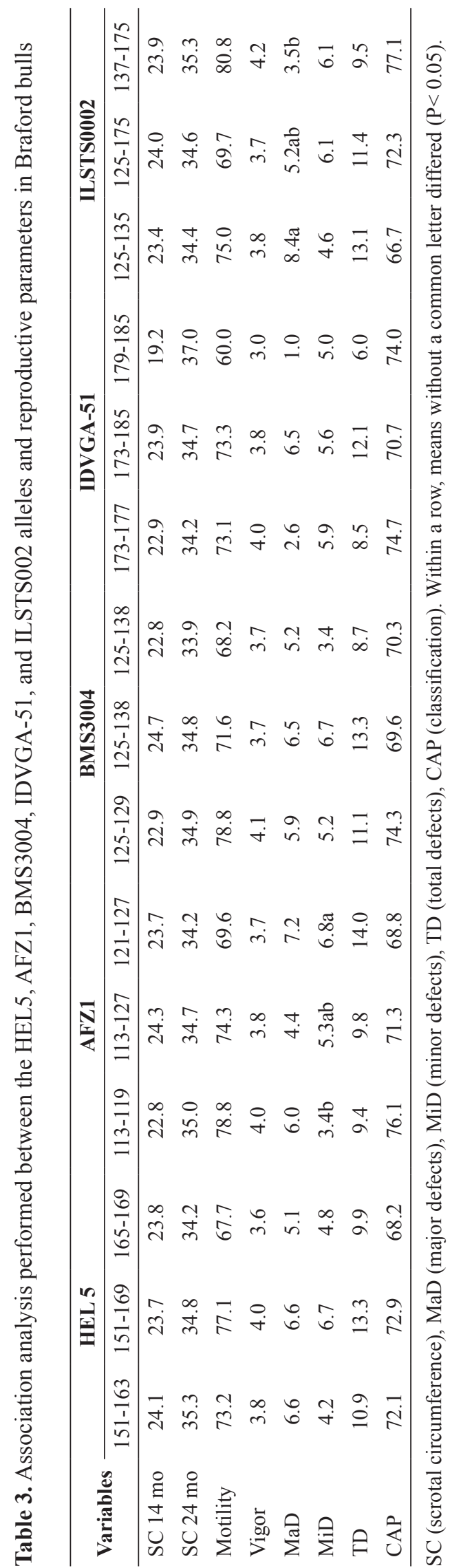


Table 4. Allele frequencies of seven molecular markers (five STRs and two SNPs) in Hereford bulls.

\begin{tabular}{|c|c|c|c|c|c|c|c|c|c|c|}
\hline \multirow{2}{*}{$\begin{array}{l}\text { Markers } \\
\text { SRTs }\end{array}$} & \multicolumn{8}{|c|}{ Alleles (\%) } & \multirow[t]{2}{*}{$\mathbf{H}$} & \multirow[t]{2}{*}{ PIC } \\
\hline & & & & & & & & & & \\
\hline \multirow[t]{2}{*}{ AFZ1 } & 113 & 117 & 119 & 121 & 123 & 125 & & & & \\
\hline & 32.0 & 25.3 & 3.6 & 13.4 & 11.3 & 11.3 & & & 0.78 & 0.75 \\
\hline \multirow[t]{2}{*}{ HEL5 } & 153 & 155 & 157 & 159 & 163 & 165 & 167 & 169 & & \\
\hline & 11.9 & 4.6 & 4.6 & 0.5 & 14.9 & 34.5 & 25.3 & 3.6 & 0.76 & 0.73 \\
\hline \multirow[t]{2}{*}{ ILSTS002 } & 125 & 127 & 129 & 133 & 135 & 137 & 139 & 141 & & \\
\hline & 2.6 & 10.8 & 5.2 & 5.2 & 38.1 & 31.4 & 5.2 & 1.5 & 0.73 & 0.68 \\
\hline \multirow[t]{2}{*}{ IDGVA-51 } & 175 & 177 & 179 & 181 & 183 & 185 & & & & \\
\hline & 43.8 & 22.7 & 27.8 & 4.6 & 0.5 & 0.5 & & & 0.68 & 0.62 \\
\hline \multirow[t]{2}{*}{ BMS3004 } & 125 & 127 & 129 & 131 & 135 & & & & & \\
\hline & 42.3 & 40.7 & 10.8 & 5.7 & 0.5 & & & & 0.64 & 0.57 \\
\hline \multicolumn{11}{|l|}{ SNPs } \\
\hline \multirow[t]{2}{*}{ LH-R } & $\mathrm{T}$ & $\mathrm{C}$ & & & & & & & & \\
\hline & 40.5 & 59.5 & & & & & & & 0.49 & 0.36 \\
\hline \multirow[t]{2}{*}{ FSH-R } & $\mathrm{G}$ & $\mathrm{C}$ & & & & & & & & \\
\hline & 57.5 & 42.5 & & & & & & & 0.49 & 0.36 \\
\hline
\end{tabular}

H, Nei's heterozygosity expected; PIC, polymorphism information content. 

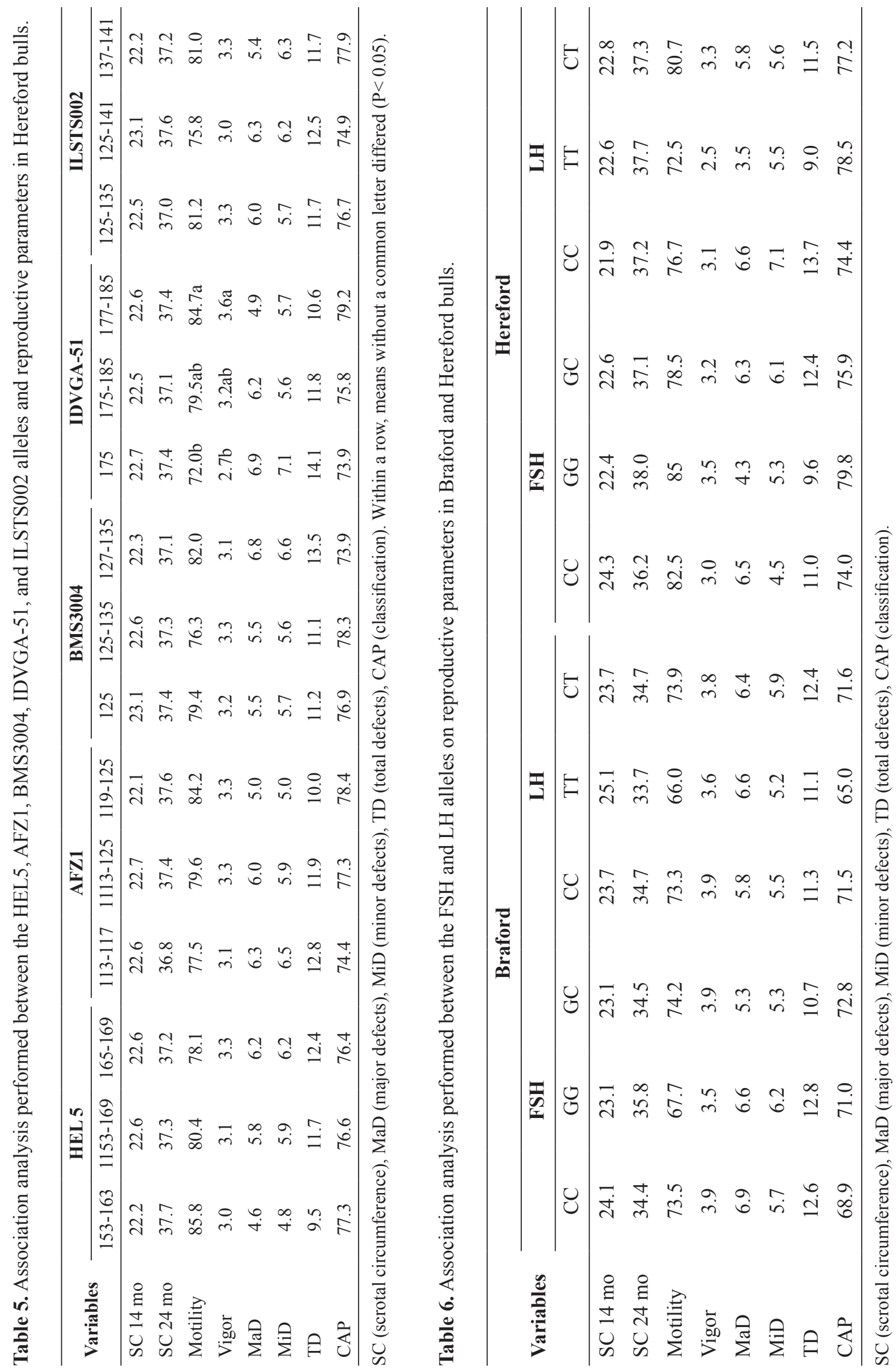


\section{Discussion}

It was possible to identify three STR markers for the analyzed population. In contrast, we observed that the SNP markers showed no difference for the reproductive parameters evaluated in our study, which might be related to the individual variability for reproductive traits in commercial herds. Major genes have a role in the expression of traits responsible for the manifestation of reproductive phenotypes (MONTALDO, 2006). The study of the genome in domestic animals is the focus of many researchers to develop a genetic map for cattle that can be used to identify chromosomal attributes that determine production characteristics.

Microsatellites have proposed markers for the determination and verification of parentage in cattle herds. In this way, the Braford breed presents a higher $\mathrm{H}$ (35 to $81 \%$ ) and the Hereford breed presents a lower $\mathrm{H}$ (49 to $78 \%$ ). We also determined that the PIC ranged from 0.28 to 0.78 in Braford and from 0.36 to 0.75 in Hereford bulls, similarly obtained using $\mathrm{H}$. We observed low variability in the data used for the animals evaluated in our study. These lower H and PIC values may be attributed to a more select group of animals used in this population, based on breeding criteria used by the farmers. In contrast, Silveira et al. (2013) observed a higher H (62\%) and PIC (0.23 to 0.87$)$ in herds classified more generally as fertile and subfertile groups of crossbred beef cows.

The association of markers with reproductive efficiency has been observed in previous studies using female bovine animals; however, few studies have been conducted to evaluate male performance (HAWKEN et al., 2012; OLIVEIRA et al., 2002). Seminal characteristics in bulls are affected by many factors, including age, testicular volume, dietary nutrition, time and place of the reproductive evaluation, environmental seasonality, and body condition (CHACON et al., 2002; FUERST-WALTL et al., 2006). Reproductive parameters, such as SC and BBSE, are commonly used to estimate the potential for individual bull fertility (FORDYCE et al., 2014).

Several markers have been used to identify their possible play on reproductive performance in many species. Molecular markers such as AFZ1, BMS3004, HEL5, ILSTS002, and IDVGA51 are located close to the genes, as intergenic regions. In addition, the LHR and FSHR markers are located in exon 11 and exon 10 on chromosome 11, respectively (LUSSIER et al., 1995; MARSON et al., 2005), and may play a role in silencing or changing its protein amino acid composition. Indeed, molecular markers have been widely used to investigate genes that code for important traits in animal production (ALMEIDA et al., 2000; MACHADO et al., 2003).

The AFZ1 and ILSTS002 markers showed changes in minor and major defects in the semen parameters in the Braford breed. Thus, their identification is useful for estimating reproductive parameters for $I G F-I R$ and $L H \beta$, which are indicators of the onset of puberty during animal growth and related to physiological development. Liron et al. (2012) studied GnRHR, LHR, and IGF-I polymorphisms according to the age of puberty in Angus bulls and observed that only $I G F-I$ is involved in the events that precede and initiate puberty in bull calves. IGF-IR shows an association with greater calving interval (OLIVEIRA et al., 2002). Perhaps the $I F G$ and $I G F-I R$ pathway is of particular importance for the age of puberty among Brahman animals, as suggested by previous results (FORTES et al., 2013; JOHNSTON et al., 2009).

Aguiar et al. (2008) studied molecular marker associations between STR ILSTS002 connected to $L H \beta$ and SNP linked to FSHR to ovulation performance and demonstrated them to be $100 \%$ (GG) homozygous for the SNP within FSHR in Angus cows. Polymorphisms found in FSHR are associated with reproductive characteristics in testicular volume in men (GRIGOROVA et al., 2013). The LH and FSH gonadotrophic hormones 
have their action mediated via binding to specific receptor membranes of target cells that are essential to puberty appearance; however, mutations in this receptor can alter the interaction between hormone and receiver that modifies the transduction of the endocrine signal and interferes with the expected physiological response (AITTOMAKI et al., 1995; FORTUNE, 1994).

In Nellore females, studies have demonstrated lower $\mathrm{H}$ values for LHR of 0.430 (MILAZZOTTO et al., 2008). Interestingly, we described a closer population genetic diversity when Braford (35\%) and Hereford (49\%) bulls were evaluated. We also observed a higher $\mathrm{H}$ for Braford and Hereford (49\%) animals, in agreement with Marson et al. (2005), that also showed a higher frequency of heterozygotes evaluated in all breed compositions in their study. The SNP study on markers for LHR and FSHR has enabled the genotype identification as well as the heterozygote structure of the population studied.

Specifically, the AFZ1 marker, which is associated with $I G F-I R$, is known to be important to germ cell development, particularly in the presence of increased IGF-I hormonal concentrations in human seminal plasma, which is significantly correlated with the percentage of morphologically normal spermatozoa and sperm concentration (GLANDER et al., 1996). Henricks et al. (1998) used computer-assisted sperm analysis (CASA) to determine the effects of IGF-I and IGF-II on bovine sperm parameters and observed an increase in sperm motility and straight-line velocity. The same authors suggest that the presence of IGF-I in semen and the ability of IGF-I to stimulate sperm motility play a possible regulatory role in spermatozoa prefertilization events in bovine species (HENRICKS et al., 1998). Indeed, studies have provided evidence that the presence of IGF-I in the male reproductive tract exerts a direct, as well as an indirect, influence on steroidogenesis (SAEZ et al., 1988) and cell proliferation and differentiation (OONK; GROOTEGOED, 1988).
The presence of the IDVGA-51 marker in Hereford bulls may indicate a change in spermatozoa motility, which might be associated with fertility performance. However, lower spermatozoa motility (72\%) and vigor (2.7\%) were observed at a higher frequency in bulls carrying the short IDVGA-51*175 allele than in animals carrying a longer IDVGA-51*175-185 allele. In fact, reproductive parameters that are subjectively classified, such as sperm motility, were considered adequate in all animals evaluated in this study, thus indicating the greater selection of bulls in a somewhat small sample size.

The $L E P$ gene has also been studied in cows and is directly related to the presence of marker alleles for IDVGA-51, which indicates an increasing calving interval in bovine females (ALMEIDA et al., 2003). Moreover, Silveira et al. (2013) observed better reproductive performance in animals carrying the short IDVGA-51 allele (173-177 bp) than in animals carrying a longer allele (IDVGA-51*181), which had been classified as subfertile because they did not calve in the previous reproductive season and remained open after two breeding seasons. Cows carrying the IDVGA-51*181 allele showed a higher expression of $L E P$ in the subcutaneous tissue, which is important in determining the nutritional effect on the animal's reproductive performance (ALMEIDA et al., 2000, 2003). Indeed, the LEP hormone serves as a metabolic signal of energy balance within the neuroendocrine system, and LEP mRNA is present in bull spermatozoa and plays an important role with physiological effects (NIKBAKHT et al., 2010). Evidence exists that $L E P$ and its receptor are also important in energy metabolism and sperm capacitation (AQUILA et al., 2008). In bulls, parameters such as motility are used to predict reproductive potential; furthermore, the identification of the IDVGA-51 allele suggests a potential marker for reproductive assessment in bovines. 
We observed a higher percentage of spermatozoa showing major morphology defects in Braford bulls carrying the short ILSTS002 allele (125-135 bp) than in animals carrying a longer ILSTS002 allele (137-175 bp). In addition, we also observed a higher H (77\%) and PIC (0.73\%) when ILSTS002 was evaluated in our Braford population. Cows with the ILSTS002 allele (135 and $137 \mathrm{bp}$ ) showed lower viable embryos and higher calving intervals, indicating a disadvantage in reproductive performance in this species (SILVEIRA et al., 2013; WEIMER et al., 2007). In our study, we observed an increase in minor spermatozoa defects in bulls carrying a longer AFZ1 allele (121 and $127 \mathrm{bp}$ ) compared to animals carrying the short allele (113 and $119 \mathrm{bp}$ ). Oliveira et al. (2005) evaluated the AFZ1 marker in a herd of Ibagé cows and found a significant effect from the favorable genotypes for AFZ1 microsatellites compared to a lower calving interval. In addition, the presence of the AFZ1 allele showed an association with beef cow pregnancy rates when fixed-time artificial insemination was used (OLIVEIRA et al., 2005; SILVEIRA et al., 2013). These results demonstrate a significant association between the markers associated with $I G F-I R$ and the reproductive performance of beef cows. Our results corroborate the findings in cows; however, the reproductive parameters evaluated in the selected bulls are variable, and further investigation is needed if these markers are to be used as a molecular tool for genetic selection in cattle.

AFZ1*121-127 associated to IGF-IR showed the highest minor defects, and ILSTS002*125-135 associated to $L H \beta$ showed the highest major defects from ejaculated semen in Braford bulls. In addition, IDVGA-51*175 associated to LEP showed lower motility and vigor in Hereford bulls.

\section{Conclusions}

The markers AFZ1 (IGF-IR) and ILSTS002 $(L H \beta)$ in Braford bulls and IDVGA-51 (LEP) in Hereford bulls were effective in verifying reproductive traits of the bulls. Complementary studies are necessary to confirm the allelic frequency established from the data collected in the current study of selected bulls in Brazil.

\section{References}

AGUIAR, P. R. Estudo de Marcadores Moleculares (Microsatélites) em Vacas Doadoras do Embriões com diferentes Respostas Superovulatórias. 2008. Tese (Doutorado em Ciências Veterinárias) - Universidade Federal do Rio Grande do Sul, Rio Grande do Sul.

AITTOMAKI, K.; DIEGUES, J. L. L.; PAKARINEN, P.; SISTONEN, P.; TAPANAINEN, J.; GROMOLL, J.; KASKIKARI, R.; SANKILA, E. M.; LEHVÄSLAIHO, H.; ENGEL, A. R.; NIESCHLAG, E.; HUHTANIEMI, I.; DE LA CHAPELLE, A. Mutation in FSH receptor gene causes hereditary hipergonadotropic ovarian failure. Cell, Cambridge, v. 82, n. 6, p. 959-968, 1995.

ALMEIDA, S. E. M.; ALMEIDA, E. A.; MORAES, J. F. C.; WEIMER, T. A. Molecular markers in the LEP gene and reproductive performance of beef cattle. Journal of Animal Breeding and Genetics, Medford, v. 120, n. 2, p. 106-113, 2003.

ALMEIDA, S. E. M.; MACHADO, M. S. N.; STEIGLEDER, C. S.; GAMA, C. L.; HUTZ, M. L.; HENKES, L. E.; MORAES, J. F. C.; WEIMER, T. A. Genetic diversity in a Brazilian bovine herd based on four microsatellite loci. Genetics and Molecular Biology, São Paulo, v. 23, n. 2, p. 347-350, 2000.

AQUILA, S.; RAGO, V.; GUIDO, C.; ZUPO, S.; CASABURI, I.; CARPINO, A. Leptin and leptin receptor in pig spermatozoa: evidence of their involvement in sperm capacitation and survival. Reproduction, Bristol, v. 136, n. 1, p. 23-32, 2008.

BARENDSE, W.; VAIMAN, D.; KEMP, S. J.; SUGIMOTO, Y.; ARMITAGE, S. M.; WILLIAMS, J. L.; SUN, H. S.; EGGEN, A.; AGABA, M.; ALEYASIN, S. A.; BAND, M.; BISHOP, M. D.; BUITKAMP, J.; BYRNE, K.; COLLINS, F.; COOPER, L.; COPPETTIERS, W.; DENYS, B.; DRINKWATER, R. D.; EASTERDAY, K.; ELDUQUE, C.; ENNIS, S.; ERHARDT, G.; FERRETTI, L.; FLAVIN, N.; GAO, Q.; GEORGES, M.; GURUNG, R.; HARLIZIUS, B.; HAWKINS, G.; HETZEL, J.; HIRANO, T.; HULME, D.; JORGENSEN, C.; KESSLER, M.; KIRKPATRICK, B. W.; KONFORTOV, B.; KOSTIA, S.; KUHN, C.; LENSTRA, J. A.; LEVEZIEL, H.; LEWIN, H. A.; LEYHE, B.; LIL, L.; BURRIEL, I. M.; MCGRAW, R. 
A.; MILlER, J. R.; MOODY, D. E.; MOORE, S. S.; NAKANE, S.; NIJMAN, I. J.; OLSAKER, I.; POMP, D.; RANDO, A.; RON, M.; SHALOM, A. J.; THIEVEN, U.; URQUHART, B. G. D.; VAGE, I.; DE WEGHE, A. V.; VARVIO, S.; VELMALA. R.; VILKKI, J.; WEIKARD, R.; WOODSIDE, C.; WOMACK, J. E. A medium-density genetic linkage map of the bovine genome. Mammalian Genome, New York, v. 8, n. 1, p. 21-28, 1997.

BARTH, A. D.; OMINSKI, K. H. The relationship between scrotal circumference at weaning and at one year of age in beef bulls. The Canadian Veterinary Journal, Ontario, v. 41, n. 7, p. 541-546, 2000.

BISHOP, M. D.; KAPPES, S. M.; KEELE, J. W.; STONE, R. T.; SUNDEN, S. L. F.; HAWKINS, G. A.; TOLDO, S. S.; FRIES, R.; GROSZ, M. D.; YOO, J.; BEATTIE, C. W. A genetic linkage map for cattle. Genetics, Bethesda, v. 136, n. 2, p. 619-639, 1994.

BOLIGON, A. A.; BALDI, F.; ALBUQUERQUE, L. G. Estimation of genetic parameters for body weights, scrotal circumference, and testicular volume measured at different ages in Nellore cattle. Journal of Animal Science, Champaign, v. 88, n. 4, p. 1215-1219, 2010.

CHACON, J.; PEREZ, E.; RODRIGUEZ-MARTINEZ, H. Seasonal variations in testicular consistency, scrotal circumference and spermiogramme parameters of extensively reared Brahman (Bos indicus) bulls in the tropics. Theriogenology, New York, v. 58, n. 1, p. 41-50, 2002.

CHENG, K. W. Properties of follicle-stimulating hormone receptor in cell membranes of bovine testis. Biochemistry Journal, Washington, v. 149, n. 1, p. 123$132,1975$.

CHENOWETH, P. J. Rationale for using bull breeding soundness evaluations. Compendium on Continuing Education for the Practicing Veterinarian, Yardley, v. 22, n. 1, p. S48-S55, 2000.

DEB, R.; KUMAR, S.; SINGH, U.; TYAGI, S.; MANDAL, D. K.; SENGAR, G.; SINGH, R.; KUMAR, M.; SHARMA, A. Evaluation of three bovine Y specific microsatellite loci as an alternative biomarkers for semen quality traits in crossbred bull. Animal Reproduction Science, Manchester, v. 142, n. 2, p. 121-125, 2013.

DEB, R.; SINGH, U.; RAJA, T. V.; KUMAR, S.; TYAGI, S.; ALYETHODI, R. R.; ALEX, R.; SENGER, G.; SHARMA, S. Designing of an Artificial Neural Network model to evaluate the association of three combined $\mathrm{Y}$ specific microsatellite loci on the actual and predicted post thaw motility in crossbred bull semen. Theriogenology, New York, v. 83, n. 9, p. 1445-1450, 2015.
FORDYCE, G.; MCGOWAN, M. R.; LISLE, A.; MULLER, T.; ALLEN, J.; DUFF, C.; HOLROYD, R. G.; CORBET, N. J.; BURNS, B. M. Scrotal circumference of Australian beef bulls. Theriogenology, New York, v. 81, n. 6, p. 805-812, 2014.

FORTES, M. R. S.; LEHNERT, S. A.; BOLORMAA, S.; REICH, C.; FORDYCE, G.; CORBET, N. J.; WHAN, V.; HAWKEN, R. J.; REVERTER, A. Finding genes for economically important traits: Brahman cattle puberty. Animal Production Science, Clayton, v. 52, n. 2-3, p. 143-150, 2012.

FORTES, M. R.; LI, Y.; COLLIS, E.; ZHANG, Y.; HAWKEN, R. J. The IGF1 pathway genes and their association with age of puberty in cattle. Animal Genetics, Oxford, v. 44, n. 1, p. 91-95, 2013.

FORTUNE, J. E. Ovarian follicular-growth and development in mammals. Biology of Reproduction, Oxford, v. 50, n. 2, p. 225-232, 1994.

FUERST-WALTL, B.; SCHWARZENBACHER, H.; PERNER, C.; SOLKNER, J. Effects of age and environmental factors on semen production and semen quality of Austrian Simmental bulls. Animal Reproduction Science, Manchester, v. 95, n. 1, p. 27-37, 2006.

GLANDER, H. J.; KRATZSCH, J.; WEISBRICH, C.; BIRKENMEIER, G. Andrology: Insulin-like growth factor-I and $\alpha 2$-macroglobulin in seminal plasma correlate with semen quality. Human Reproduction, Oxford, v. 11, n. 11, p. 2454-2460, 1996.

GRIGOROVA, M.; PUNAB, M.; POOLAMETS, O.; SÕBER, S.; VIHLJAJEV, V.; ŽILAITIENĖ, B.; ERENPREISS, J.; MATULEVIČIUS, V.; TSAREV, I.; LAAN, M. Study in 1790 Baltic men: FSHR Asn680Ser polymorphism affects total testes volume. Andrology, Oxford, v. 1, n. 2, p. 293-300, 2013.

HAWKEN, R. J.; ZHANG, Y. D.; FORTES, M. R.; COLliS, E.; BARRIS, W. C.; CORBET, N. J.; WILLIAMS, P. J.; FORDYCE, G.; HOLROYD, R. G.; WALKLEY, J. R.; BARENDSE, W.; JOHNSTON, D. J.; PRAYAGA, C. K.; TIER, B.; REVERTER, A.; LEHNERT, S. A. Genome-wide association studies of female reproduction in tropically adapted beef cattle. Journal of Animal Science, Champaign, v. 90, n. 5, p. 1398-1410, 2012.

HENRICKS, D. M.; KOUBA, A. J.; LACKEY, B. R.; BOONE, W. R.; GRAY, S. L. Identification of insulinlike growth factor I in bovine seminal plasma and its receptor on spermatozoa: influence on sperm motility. Biology of Reproduction, Oxford, v. 59, n. 2, p. 330-337, 1998. 
HOUDE, A.; LAMBERT, A.; SAUMANDE, J.; SILVERSIDES, D. W.; LUSSIER, J. G. Structure of the bovine follicle-stimulating hormone receptor complementary DNA and expression in bovine tissues. Molecular Reproduction and Development, Oxford, v. 39, n. 2, p. 127-135, 1994.

JOHNSTON, D. J.; BARWICK, S. A.; CORBET, N. J.; FORDYCE, G.; HOLROYD, R. G.; WILLIAMS, P. J.; BURROW, H. M. Genetics of heifer puberty in two tropical beef genotypes in northern Australia and associations with heifer and steer production traits. Animal Production Science, Clayton, v. 49, n. 3, p. 399412, 2009.

JORGENSEN, C. B.; KONFORTOV, B. A.; MILLER, J. R. A polymorphic microsatellite locus (AFZ1) derived from a bovine brain cortex cDNA library. Animal Genetics, Oxford, v. 27, n. 3, p. 220-220, 1996.

KAPPES, S. M.; KEELE, J. W.; STONE, R. T.; MCGRAW, R. A.; SONSTERGARD, T. S.; SMITH, T. P. L.; LOPEZ-CORRALEZ, N. L.; BEATTIE, C. W. A second-generation linkage map of the bovine genome. Genome Research, Bethesda, v. 7, n. 2, p. 235-249, 1997.

KASTELIC, J. P.; THUNDATHIL, J. C. Breeding soundness evaluation and semen analysis for predicting bull fertility. Reproduction in Domestic Animal, Oxford, v. 43, n. 3, p. 368-373, 2008.

KEMP, S. J.; BREZINSKY, L.; TEALE, A. J. ILSTS002: a polymorphic bovine microsatellite. Animal Genetics, Oxford, v. 23, n. 2, p. 184-184, 1992.

LAHIRI, D. K.; ZHANG, A.; NURNBERGER, J. I. High-resolution detection of PCR products from a microsatellite marker using a nonradioisotopic technique. Biochemical and Molecular Medicine, Amsterda, v. 60, n. 1, p. 70-75, 1997.

LIRON, J. P.; PRANDO, A. J.; FERNÁNDEZ, M. E.; RIPOLI, M. V.; ROGBERG-MUÑOZ, A.; GOSZCZYNSKI, D. E.; POSIK, D. M.; PERALGARCÍA, P.; BALDO, A.; GIOVAMBATTISTA, G. Association between GnRHR, LHR and IGF1 polymorphisms and timing of puberty in male Angus cattle. BMC Genetics, New York, v. 13, n. 1, p. 26-31, 2012.

LUSSIER, J. G.; HOUDE, A.; ETHIER, J.; SILVERSIDES, D. W. Bos taurus luteinizing hormone receptor mRNA. Genbank accession number: U20504. 1995.

MA, T. H.; XIONG, Q. H.; YUAN, B.; JIANG, H.; GAO, Y.; XU, J. B.; LIU, S. Y.; DING, Y.; ZHANG, G. L.; ZHAO, Y. M.; ZHANG, J. B. Luteinizing hormone receptor splicing variants in bovine Leydig cells.
Genetics and Molecular Research, Ribeirão Preto, v. 11, n. 2, p. 1721-1730, 2012.

MACHADO, M. A.; SCHUSTER, I.; MARTINEZ, M. L.; CAMPOS, A. L. Genetic diversity of four cattle breeds using microsatellite markers. Revista Brasileira de Zootecnia, Viçosa, MG, v. 32, n. 1, p. 93-98, 2003.

MARSON, E. P.; FERRAZ, J. B.; MEIRELLES, F. V.; BALIEIRO, J. C.; ELER, J. P.; FIGUEIREDO, L.G.; MOURÃO, G. B. Genetic characterization of EuropeanZebu composite bovine using RFLP markers. Genetics and Molecular Research, Ribeirão Preto, v. 30, n. 3-4, p. 496-505, 2005.

MENEGASSI, S. R. O.; BARCELLOS, J. O. J.; PERIPOLLI, V.; PEREIRA, P. R. R.; BORGES, J. B. S.; LAMPERT, V. N. Measurement of scrotal circumference in beef bulls in Rio Grande do Sul. Arquivo Brasileiro de Medicina Veterinária e Zootecnia, Belo Horizonte, v. 63, n. 1, p. 87-93, 2011.

MILAZZOTTO, M. P.; RAHAL, P.; NICHI, M.; MIRANDA-NETO, T.; TEIXEIRA, L. A.; FERRAZ, J. B. S.; ELER, J. P.; CAMPAGNARI, F.; GARCIA, J. B. S. New molecular variants of hypothalamus-pituitarygonad axis genes and their association with early puberty phenotype in Bos taurus indicus (Nellore). Livestock Science, Amsterda, v. 114, n. 2-3, p. 274-279, 2008.

MILLER, S. A.; DYKES, D. D.; POLESKY, H. F. A simple salting out procedure for extracting DNA from human nucleated cells. Nucleic Acids Research, Oxford, v. 16, n. 5, p. 1215-1215, 1998.

MONTALDO, H. H. Genetic engineering applications in animal breeding. Electronic Journal of Biotechnology, Valparaíso, v. 9, n. 2, p. 157-170, 2006.

NEI, M. Estimation of average heterozygosity and genetic distance from a small number of individuals. Genetics, Bethesda, v. 89, n. 3, p. 583-590, 1978.

NIKBAKHT, G.; ROOSTAEI ALI MEHR, M.; BAGHBANZADEH, A.; TAJIK, P.; TAMANINI, C.; EMAM, M. Leptin receptor mRNA in bull ejaculated spermatozoa. Reproduction in Domestic Animals, Oxford , v. 45, n. 2, p. 237-242, 2010.

OLIVEIRA, J. F. C.; NEVES, J. P.; ALMEIDA, E. A.; STEIGLEDER, C. S.; MORAES, J. F. C.; GONÇALVES, P. B. D.; WEIMER, T. A. Association between reproductive traits and four microsatellites in Brangus-Ibage cattle. Genetics and Molecular Biology, São Paulo, v. 28, n. 1, p. 54-59, 2005.

OLIVEIRA, J. F. C.; NEVES, J. P.; MORAES, J. C.; GONÇALVES, P. B. D.; BAHR, J. M.; HERNANDEZ, A. G.; COSTA, L. F. Follicular development and steroid 
concentrations in cows with different levels of fertility raised under nutritional stress. Animal Reproduction Science, Manchester, v. 73, n. 1, p. 1-10, 2002.

OONK, R. B.; GROOTEGOED, J. A. Insulin-like growth factor I (IGF-I) receptors on Sertoli cells from immature rats and age-dependent testicular binding of IGF-I and insulin. Molecular and Cellular Endocrinology, Amsterda, v. 55, n. 1, p. 33-43, 1988.

RODRIGUEZ-MARTINEZ, H. State of the art in farm animal sperm evaluation. Reproduction, Fertility and Development, Clayton, v. 19, n. 1, p. 91-101, 2007.

SAEZ, J. M.; CHATELAIN, P. G.; PERRARD-SAPORI, M. H.; JAILLARD, C.; NAVILLE, D. Differentiating effects of somatomedin-C/insulin-like growth factor $\mathrm{I}$ and insulin on Leydig and Sertoli cell functions. Reproduction Nutrition and Development, Les Ulis Cedex, v. 28, n. 4B, p. 989-1008, 1988.
SILVEIRA, J. C.; PASSOS, D. T.; GLANZNER, W. G.; AGUIAR, P. R. L.; MORAES, J. F. C.; WEIMER, T. A. Genome association analysis for pregnancy status following parturition in crossbred beef cattle. Brazilian Journal of Veterinary Research and Animal Science, São Paulo, v. 50, n. 5, p. 406-413, 2013.

WALDNER, C. L.; KENNEDY, R. I.; PALMER, C. W. A description of the findings from bull breeding soundness evaluations and their association with pregnancy outcomes in a study of western Canadian beef herds. Theriogenology, New York, v. 74, n. 5, p. 871-883, 2010.

WEIMER, T. D. A.; STEIGLEDER, C. S.; MACHADO, M. S.; ALMEIDA, S. E. M.; OLIVEIRA, J. F. C.; MORAES, J. C. F.; HENKES, L. E. Identification of molecular markers on bovine chromosome 18 associated to calving interval in a Brangus-Ibagé cattle herd. Ciência Rural, Santa Maria, v. 37, n. 5, p. 1502-1505, 2007. 
